\title{
MONITORING AND PROCESSING THE CHALLENGES OF MENTAL STABILITY IN DISASTER SITUATIONS
}

\author{
Róbert ZSAKAI, PhD*
}

There are daily news regarding social and political events, natural and civilizational disasters. Disasters have an impact both on those living in the disaster-stricken area and on the various intervening personnel. Research results have broadened human knowledge of natural and civilizational disasters. Disaster protection has increasingly evolved into a system of regulated defence involving protection of society values. The tasks of military and disaster protection are similar; however causal differences can emerge. Disaster management is now a very complex process, which is not only the task of a national organization, but also the struggle of governments and societal organizations for a common goal. For intervening personnel, processing the psychological loads with specialists becomes increasingly necessary. The role of the authorities during emergencies is of key importance in the management and coordination of actions. The need for the supporting role of international and national humanitarian organizations is also strengthening. This paper aims at presenting the elements of risk evaluation and human resilience in disaster situations, in order to understand vulnerabilities, and evaluation results should be included in contingency planning.

Keywords: disaster; crisis; mental assistance; PTSD; defence management.

\footnotetext{
* Second Lieutenant Róbert ZSAKAI, PhD, is Platoon Commander within Air Operation Command and Control Center, Garrison Support Command, Veszprém, Hungary. E-mail: info@zsrobert.com
} 


\section{Introduction}

It is an unfortunate observation that disasters and crises have increasingly become a part of our lives. The general feature of such events is endangering human life and material goods, acting in a special way, thus special methods are needed to prevent them. Disasters, catastrophic events, and the need for protection against them, are a constant issue. The original meaning of the word catastrophe of Greek origin is a turning point, or an outcome, as it means a misfortune, and a state of crisis in our current usage. An important feature of natural disasters is that their occurrence cannot be predicted precisely or frequently, they usually happen rather unexpectedly, making response attempts more difficult.

Recently, Hungarian Act CXXVIII of 2011 on Disaster Protection and Amendments to Certain Related Acts (henceforward Cat. Act), is decisive for the concept of disaster. According to its Section 3 and Clause 5, catastrophe is a condition or situation suitable for declaring a state of emergency, or not reaching the declaration of such a situation, but clearly endangers human life, health, material goods and the natural environment of a population, in such a way or to such an extent that prevention or management exceeds the possibilities and capacities of the legal organizations and, thus requires the continuous and strictly coordinated cooperation of governmental bodies and the use of international assistance. Due to disaster protection, it has become necessary to establish a system of regulated protection and prevention. Due to the diversity of tasks, it has become necessary to renew the legal regulation and practice of disaster management since January 1, 2012, from the connection to European Union. The new Cat. Act comprehensively regulates the areas of activity and responsibilities. In order to have sufficient time to prepare for the effects of predictable emergencies, the new Disaster Protection Act introduces the period of disaster risk.

An emergency situation, defined in Article 53 of the Hungarian Constitution, may be triggered, in particular, by the following events (set out in Section 44 of the new Disaster Protection Act):

- elemental disasters, natural hazards,

- industrial accidents, threats of civilizational origin,

- other hazards, disasters.

During such a period, i.e. in case of emergency, the government, to the extent and in the area necessary for the prevention of the disaster, may introduce extraordinary regulations pursuant to Cat. Act 47-48. Also, according to Cat. Act §. 49-51. it may authorize organisations with special execution of the above mentioned extraordinary regulations. During the occurrence of disasters, it was proven that defence is not only the task of a special organization, but the cooperation of the national and local governments and non-governmental organizations is necessary 
for its effectiveness.

Effective defence is depending internationally on the United Nations, the European Union, NATO as a military alliance. Additionally, locally in Hungary it is depending also on the cooperation of charities and churches. Creating and maintaining safety, developing protection against disasters is an interest to all people. The sub-areas of the different tasks and abilities of the different organisations are added together, they are such an insurance for the preparation, the reduction of the negative consequences during the defence, and the effective restoration and reconstruction. Disasters, and the need to protect against them, appear at every age. The defence management system, and the role of the authorities, is key to the management and coordination of assistance in case of an emergency, as it is their legal duty to take care of those involved.

\section{Mental Effects of Disasters}

The general feature of emergencies and disasters is large-scale destruction, which causes significant losses. They mostly happen unexpectedly, thus feelings of insecurity and vulnerability are even more expressed. Experiencing disasters directly or on the basis of indirect information can be a stressful and frustrating situation. An emergency is a special situation that directly affects both those involved and the intervening personnel, and also possibly threatens their life. Based on empirical evidence of the disaster-stricken areas, the accordingly prepared population suffers significantly smaller losses, as the explained correct behaviour, knowledge of the possibilities of self-rescue, and the ability to cooperate with the rescue forces can be crucial in case of emergency. Increasing number of literature and empirical research emphasizes the necessity of psychological preparation of both civilians and intervening personnel. With regard to the psychological phenomena that accompany disasters, it has been argued that panic is the natural mechanism that accompanies the emergency situation and acts even if we do not care about it. In some cases, a spontaneous act or statement will help the outcome of the execution, but in other cases, it can cause panic. Rapid overview, recognizing the situation, and possibly gaining previous experience can play a key role in preventing panic.

A variety of methods of psychosocial assistance allow for assistance tailored to individual and community needs. Psychosocial well-being can be considered our basic need, and if it overthrows, stabilization is needed. The processing of disasters and its psychological and social effects are different in every human being. Primary intervention professionals may need help processing what they see during an action, as well as the population experienced a disaster and waiting for help. In general, it is still not common to share our emotional, mental, or psychological problems with an outsider. This is often treated to be a sign of weakness as well 
as an indication that an individual is unable to cope with the situation on her/his own. If the danger is predicted, there may be an excessive fear of the danger in the pre-disaster phase. During disasters, the family is a strong emotional bond, that helps to process fears, failures and injuries, reduces the weight of stressful situations and relieves tension ${ }^{1}$. Fear is an essential emotional state for the body's defence, it motivates and encourages people to take action, and can trigger surviving reactions. An important feature of this stage is that people, even unconsciously, tend to behave as others do. Due to the unexpectedness of the triggering emergency event, fear can affect the individual as a shock, and their effect might build into the experience and personality of those involved. Additionally, the effects of disasters on individuals become visible and assessable only days, weeks, or months after the event ${ }^{2}$. These effects may develop anxiety, phobias, or irrational beliefs. On the other hand, the experience of a successful fear coping can also create new, enduring skills and new adaptation techniques. Clear and simple communication is needed with a person in a crisis situation. The expression of open emotion, the use of the present, past and future happenings can relax the narrow focus, i.e. the state when the person who has experienced the loss can concentrate only on the actual problem. Transparency in crisis communication is required, but it is also desirable to treat certain information as classified data, where appropriate, in order to prevent further panic. Rescue workers can face the problem of empathy as a barrier. Realistic exploration, strong management, leadership, professional intervention, assignment of logistics for rescue, credible communication can have a decisive influence on the activity, speed and problem-solving skills of intervening personnel. Moreover, several case studies conclude, that help should be proactive, as people who have suffered a disaster should not be expected to seek help, as their current mental state does not allow them to behave actively ${ }^{3}$. Professionals who want to help in disaster or crisis situations must also have psychological knowledge that can help increase the person's sense of security. Human lives are also threatened in disasterstricken areas. People can get injured, or worse, they can die. In addition, it cannot be overlooked that survivors are under significant psychological pressure, which can have serious early or late consequences that may have effects for the rest of their lives ${ }^{4}$. According to the psychological approach of the disasters, a disaster is a

\footnotetext{
${ }^{1}$ Albert-Farkas vLeveleki, Szociológia, Möbius Print, Nyíregyháza,2001, p. 114.

$2 * * *$, Segítségnyújtás katasztrófa és terrortámadás esetén - Belga Vöröskereszt kiadványa, Eureste Handbook, Brüsszel, 2006.

$3 * * *$, Enhancing psychological support, Internation of Red Cross: IFRC. Geneva, 2007.

${ }^{4}$ Zsuzsanna Kaló, A korai és késői pszichés jelenségek katasztrófák során, és a káros hatások elkerülésének lehetséges módjai, MÜSZAKI KATONAI KÖZLÖNY, XXI.évf.12. sz. különszám, 2011, Budapest, NKE HHK MHTT, Müszaki Szakosztály, URL: http://www.hhk.uni-nke.hu/ downloads/kiadvanyok/mkk.uni-nke.hu/eloadasokpdf/3.csop/Kalo\%20Zsuzsanna.pdf, accessed on 25. 04.2014.
} 
psychologically devastating event outside the range of normal human experiences, which can lead to abnormal behavioural reactions with certain symptoms ${ }^{5}$. In many cases, spiritually unprocessed experiences return to memory and can make everyday life difficult because of their depressing weight.

Mass panic is a specific form of community behaviour that greatly aggravates and even hinders escape and survival, and also makes the work of rescuers more difficult $^{6}$. For example, right after the disaster of the Titanic cruise ship, the basic moral principle of giving priority to the rescue of women, children and the elderly are ruined soon. Men tried to find a place in lifeboats in women's clothing, others tried to get a life jacket threatening with a knife ${ }^{7}$. Common features of people in the stage of panic are loss of judgment and extreme emotional outbursts. Also, the loss of moral control and the disregard for community norms are common in such situations of panic. In other cases, for example in a traffic accident with many fatalities, depression, helplessness, guilt and anxiety about the failure can be observed, more likely in rescue personnel ${ }^{8}$.

At national defence and disaster management forces, it is more common that the members of the intervention staff can manage to overcome fear and other depressing feelings in many cases, but there are those whose mental stability does not return to its equilibrium position because their resources have been damaged as a result of various stress reactions. In their case, crisis intervention is necessary ${ }^{9}$ Crisis intervention is aimed at resolving a crisis situation with the intention of helping. Crises are characterized by anxiety and fear. Only few psychical diseases are known to have a psychiatric condition whose characteristics have not changed over the centuries. Depression is a universal problem that can be experienced by either the injured or the helpers even after disasters. Usually, depression is a transient condition that persists for a short time, provided the person settles his or her mental state and changes his or her way of thinking about himself or herself and the particular problem ${ }^{10}$. The diagnosis of the disease is based on an examination of the patient's mental state, and although medical solutions are improving, unfortunately, doctors are constantly looking for a truly effective way to cure depression. The

\footnotetext{
${ }^{5}$ Judit Bolgár, György Szekeres, Katasztrófa és kríziskommunikáció lélektani alapjai. Elektronikus jegyzet a Védelem Igazgatás szereplői számára, Bp.:ZMNE, 2009, URL: https://adoc.pub/katasztrofaes-kriziskommunikacio-lelektani-alapjai.html

${ }^{6}$ Róbert, Zsákai, A lelki segitségnyújtás jelentősége katasztrófák során, URL: https://www.knbsz. gov.hu/hu/letoltes/szsz/2014_1_szam.pdf, accessed on 06.07.2021.

${ }^{7}$ Iván Kéménczy, Tömegkatasztrófák pszichológiai hatásai, Zrínyi Katonai Kiadó, Budapest, 1980, pp. 31-32.

${ }^{8}$ Barlai Róbert PhD, Kővágó György, Válság-(katasztrófa) kommunikáció, Petit Real Könyvkiadó, Budapest, 1996, p. 31.

${ }^{9}$ Zelimir Pavlina, Zoran Komar, Military Psychology, vol. II, Zrínyi Publishing House, 2007.

${ }^{10}$ Tim Lahaye, Gyözelem a depresszió felett, Budapest, 1998, p. 243.
} 
issue of mental assistance is a great opportunity, because if people's mental wellbeing deteriorates, the solution of problems, the management of a disaster, a crisis, and the elimination of its consequences are also endangered.

\section{Hungarian and International Possibilities for Disaster Management}

The continuously changing environment requires the individual, organisation, and group as units to adapt quickly and professionally. The infamous red mud catastrophe on October 4, 2010 was the biggest industrial disaster in Hungary's modern history. It also surpassed the devastation of natural disasters in terms of its fatalities and the human and material damage it caused. The disaster caused by the damage to the sludge reservoir of Hungarian Aluminium Factory MAL Zrt. damaged the population and material goods of the settlements, and also the natural environment in connection with water and soil pollution. Throughout the management of the events, the cooperation of the ministries, construction sector, national organisations and the participation of science were outstanding. The disaster mobilized a very significant social cohesion and helpful intention ${ }^{11}$. It was clear that disaster management is also at the forefront of assistance in performing civil protection, industrial safety and fire protection tasks. In the red mud disaster, humanitarian organizations were in great need in addition to professional and national organisations, as they serve significant donations, money, services, psychological support, the provision of rentals, and the construction of new houses to help the disaster-stricken population. At the local, regional and national levels, disaster management forces must support population preparation and protection activities, as well as participate in the planning, organization and implementation of recovery tasks. Otherwise, when dealing with a crisis, aid organizations and military should cooperate to safely deliver aid supplies to the scene of the disaster. Civilian-military cooperation has an important role to play in utilizing civilianmilitary resources, supporting humanitarian missions, and ensuring the success of military operations ${ }^{12}$. International and national organizations may aim to provide disaster relief at the request of the governments of endangered countries with the approval of the government of the assisting country, as Hungarian government did in 2021, at the request of the Croatian government after a serious earthquake near Petrinje.

In conclusion, the goal is to save human lives and material goods in all cases, but also to mobilize material supplies and humanitarian resources. Various non-

\footnotetext{
${ }^{11}$ Árpád Muhoray, Antal Papp, A vörösiszap-katasztrófa elleni védekezés, a helyreállitás, újjáépités tapasztalatai, vol. II, Belügyi Szemle, 2013, pp. 84-85.

12 József Padányi, Polgári-katonai együttmüködés a békefenntartó műveletek során, ZMNE, Budapest, 2001, p. 6.
} 
governmental organizations, associations and churches play an inclusive role for the people affected by disasters, provide assistance with practical measures, social and legal assistance. They also provide psychosocial and mental assistance to stakeholders, and, if necessary, they are referred to a psychologist or other professional ${ }^{13}$. Every organisation should help as they can do. For example, in the case of the already mentioned red mud disaster, a local radio was operated in the church of Devecser, which was part of the communication tools of informing the local population, and the church also played a huge role in the distribution of charitable donations. The tourist accommodation of the church in Kolontár, together with the military leading colleagues of RZs, provided a few hours of sleep possibility for intervention staff at night during the initial period of rescue management.

In order to understand psychic effects, we need to know what the accompanying phenomena that trigger a negative psychic effect in a disaster are. Every disaster is different, but by examining disaster events, some accompanying phenomena can be identified that should always be taken into account in these areas ${ }^{14}$. If the symptoms associated with anxiety appear within four weeks of the traumatic event and last for 2-28 days, we call it acute stress disorder ${ }^{15}$. That is why it is necessary for a team of psychiatrists, psychologists, pastors and family helpers to immediately help those in need in the areas affected by the disaster. Fear is a very important emotional state for the body's defence, as it makes it easy to avoid danger and can trigger instinctive, surviving reactions. Existential anxiety is a general human fear arising from the limitations and responsibilities of our existence. We are anxious because we recognize that life is not infinite, and also the inevitability of death ${ }^{16}$.

Churches are not political communities, but primarily spiritual, moral leaders. Experience shows that believers are generally more stable mentally, less prone to panic during emergencies, and can be involved in defence more easily. When a disaster occurs, believers often face the situation with more hope despite the difficulties. Based on research, people are also greatly influenced by the culture of a given country. Knowing and understanding the culture mean that everyone can and does have a role to play in creating and maintaining safety, including churches ${ }^{17}$. The Hungarian government is increasingly expanding the responsibilities that can be taken over by the churches and also providing support for them. Relevant Hungarian literature on the subject also supports the fact that in addition to their religious work,

\footnotetext{
${ }^{13}$ Raquel E. Cohen, Pan American Health Organization: Mental health services in disasters: manual for humanitarian workers. PAHO, 2000, p. 223.

${ }_{14}$ Júlia Hornyacsek, A települési védelmi képességek a katasztrófakihívások tükrében, Oktatási és Tanácsadó Tudományos Egyesület, Budapest, 2011, pp. 40-42.

${ }^{15}$ Ronald J. Comer, A lélek betegségei, Osiris Kiadó, Budapest, 2000, p. 205.

${ }^{16}$ Ronald J. Comer, A lélek betegségei, Pszichopatológia, Osiris Kiadó, Budapest, 2005, pp. 160.

${ }^{17}$ István Bukovics, Gondolatok az egyházak szerepéről a katasztrófavédelemben, Wesley János Lelkészképző Főiskola kiadványa, Budapest, 2008, pp. 1-5.
} 
churches also play a significant role in Hungary through their cultural, educational, social and health activities, and by strengthening national consciousness. Shared responsibility makes cooperation and common actions easier ${ }^{18}$. Throughout history, during greatest dangers, churches have always been there to lend a helping hand to people in need, no matter what disaster or difficulty they have suffered. The often more difficult part of the assistance is far from material. Personal attention, the power of the community, tactful and personal counselling, social care, are fundamental elements of church and religious activities.

\section{Conclusions}

Measuring risk and capacity is an important tool for understanding people's vulnerability to disaster, and their results should be incorporated into contingency planning. Disaster mitigation and reduction activities are a major challenge, requiring significant capacity at local level, but at the same time they should be part of a comprehensive strategy. Our recent lifestyle can unfortunately be a cause for constant fear, alongside the many good and modern possibilities. The emergence of epidemics, the constant fight against disasters, terrorism are all problems in our current times. Last year's pandemic, the fight against COVID-19 has made everyday life especially difficult and uncertain. Anxiety, fears, feelings of helplessness are becoming an increasing burden on us. Doctors, healthcare workers and soldiers working on the front lines have a great responsibility. It can already be observed that the intervening personnel, those helping on the front line against COVID-19, have an increasing role to play, and they can be affected by effects that have been observed, for example, during natural disasters, or in war zones. Recent scientific results show, that recognizing the disaster management aspects of mental assistance is becoming increasingly necessary.

The experience of recent years shows that crises and disasters have become an integral part of our lives, which we cannot often avoid, but can be mitigated with sufficient preparedness. It is enough to think of September 11, 2001, or to remember the floods and dangerous extreme weather events of recent years, or the Hungarian red mud disaster. A terrorist attack has awakened and rethought the European Community's defence system, and it has become necessary to rethink and set up defence at a global community level. It has become clear that disaster management is not simply a technical or legal issue, but a complex social issue where special cases and procedures have to be reckoned with, all of which have been confirmed by international events in recent years. People must not be left in a state of vulnerability and insecurity. The previously mentioned catastrophic and panic

${ }^{18}$ Vilmos Fischl, A nemzetközi egyházi szervezetek szerepe az államközi valamint csoportok közötti konfliktusok és válságok kezelésében, Budapest, ZMNE Doktori (Phd) értekezés, 2006, pp. 56-58. 
processes and inadequate communication can also be the causes and consequences of each other. Thus, more and more people are participating in the complex process of crisis management in addition to coordinating professional disaster management. If vulnerable communities are more aware of the risks and know the basic coping strategies, they can minimize both the number of deaths and material losses, and mental injuries. National companies may encourage the establishment of "Community Emergency Committees" responsible for the planning, management and coordination of response and preparedness activities.

Churches are also playing an increasingly important role in this matter, as religion can be a part of the lives of many people. Therefore, churches are wellsuited to their organizational structure and mission, and play an important role in helping and assistance, including in disaster management. The expectation of the society is that the events that have happened should be conducted professionally, humanely and with sufficient empathy by the organisations dedicated to this. It can be said that in recent decades, churches have changed a lot, e.g. how they are living their faith or even in their structural structure, but their values have remained the same throughout, which is to protect the greatest value: human life. Military leaders can only be prepared for quick decisions in the past, considering only military factors, but nowadays, effective cooperation with civilian, governmental and non-governmental organisations are also important for leadership. After the consequences of disasters have been eliminated, an effective method of assistance to deal with current problems should always be adapted. It can also be effective to consider the possibilities of cooperation between different service areas in disaster management. Launching a detailed research program involving the churches, also based on the fact that fulfilling the role of disaster management is a national and social requirement, needs to be flexible to various natural and other changes, increased national governmental involvement and required technical developments.

Importantly, prevention always requires less expenditure than recovery and management after a disaster. Every opportunity should be taken to minimize the damage caused by forecasting each type of disaster, strengthen cooperation of different organizations to help, and train the population for disaster situations. The fight against the coronavirus is very similar to the battlefield medicine defined by military psychology: the desperate patients, the risky environment, and the fight with an invisible enemy are usually worse than a war. The emergence and global spread of the SARS-CoV2 virus in healthcare and other areas has shown how much society and economy can be burdened and how prepared they are for such problemsolving. We do not know exactly what the real enemy is, we feel a huge mental discomfort, possibilities of loss and danger. Extreme physical and mental exhaustion can be caused by a lot of bad news, which can lead to mental injuries. According to experts, more and more psychological problems are emerging from the population, 
but also from helpers, defence force, ambulance and military members. Constant daily preparedness, fears of infection, experiencing the number of deaths, and feeling helplessness can cause emotional trauma that can lead to serious mental problems. It has been observed many times that confusion can develop into post-traumatic stress disorder (PTSD). Anxiety can progress to depression, but can also lead to rapid burnout, so they can easily become a victim from a psychological point of view. The term "second victim" stated by Albert Wu, a Professor at Johns Hopkins University in Baltimore. According to Wu's scientific research, those at the forefront of helping against the epidemic should also pay attention to treating their emotions and mental health, as PTSD is an insidious syndrome that can last for more than a month and generate a re-experience of events. Hearing about deaths constantly reminds the sufferer of the negative event and helplessness. Watching a lot of negative emotions, crying, breaking up families comes with extreme stress. The unstoppable work of institutional workers, and their concerns that they could catch the infection at any time, or they can be a danger for their loved ones, places a great mental load on them. Also, soldiers participating in the hospital service must face similar problems, as there is no guarantee that they will stay healthy after the work they have done, and they have to go home to their families and loved ones carrying his burden. I am convinced that, in addition to the development of classical military capabilities, resilience is an area where planned and coordinated preparation is needed to guarantee the security of a country, and this is an area in which more human and material resources should be involved and developed. Important elements are preparation, resource storage and strategy development and practice before crises. In their absence, military force alone is unlikely to be sufficient to deal with crisis situations optimally. Psychological and emotional support is necessary to maintain the mental health of all workers and helping staff. Also, mental assistance represents a great support in these times, because if workers' mental health deteriorates, the problem, disaster, crisis management and elimination of its consequences are endangered.

\section{BIBLIOGRAPHY:}

1. ***, Enhancing psychological support, Internation of Red Cross, IFRC, Geneva, 2007.

2. ***, Segítségnyújtás katasztrófa és terrortámadás esetén - Belga Vöröskereszt.

3. BARLAI, Róbert; KÖVÁGÓ, György, Válság-(katasztrófa) kommunikáció, Petit Real Publishing House, Budapest, 1996.

4. BOLGÁR, Judit; SZEKERES, György, Katasztrófa és kríziskommunikáció lélektani alapjai, Elektronikus jegyzet a Védelem Igazgatás szereplői számára, ZMNE, Budapest, 2009, URL: https://adoc.pub/katasztrofa-es-kriziskommunikacio- 
lelektani-alapjai.html

5. BUKOVICS, István, Gondolatok az egyházak szerepéről a katasztrófavédelemben, Wesley János Lelkészképző Főiskola kiadványa, Budapest, 2008.

6. COHEN, E. Raquel, Pan American Health Organization: Mental health services in disasters, manual for humanitarian workers, PAHO, 2000.

7. COMER, J. Ronald, A lélek betegségei, Pszichopatológia, Osiris Kiadó, Budapest, 2005.

8. COMER, J. Ronald, A lélek betegségei. Osiris Kiadó, Budapest, 2000.

9. FISCHL, Vilmos, A nemzetközi egyházi szervezetek szerepe az államközi valamint csoportok közötti konfliktusok és válságok kezelésében, Budapest, ZMNE Doktori (Phd) értekezés, 2006.

10. HORNYACSEK, Júlia, A települési védelmi képességek a katasztrófakihívások tükrében, Oktatási és Tanácsadó Tudományos Egyesület, 2011, Budapest.

11. KÁDÁR, Pál, A pandémia kezelése mint a nemzeti ellenálló képesség "tesztje", Honvédségi, vol. 149, no. 2/2021.

12. KALÓ, Zsuzsanna, “A korai és késői pszichés jelenségek katasztrófák során, és a káros hatások elkerülésének lehetséges módjai", Müszaki Katonai Közlöny, XXI. évf. 12. sz. különszám, Budapest, 2011, URL: http://www.hhk. uni-nke.hu/downloads/kiadvanyok/mkk.uni-nke.hu/eloadasokpdf $/ 3 . c s o p / K a l o \%$ 20Zsuzsanna.pdf

13. KÉMÉNCZY, Iván, Tömegkatasztrófák pszichológiai hatásai, Zrínyi Military Publishing House, Budapest, 1980.

14. kiadványa, Eureste Handbook, Brüsszel, 2006.

15. LAHAYE, Tim, Győzelem a depresszió felett, Budapest, 1998.

16. LEVELEKI Albert-Farkas, Szociológia, Möbius Print, Nyíregyháza,2001.

17. MUHORAY, Árpád, A 2001-es beregi árvíz tizedik évfordulóján túl, Belügyi szemle, 60, 2012.

18. MUHORAY, Árpád; PAPP, Antal, A vörösiszap-katasztrófa elleni védekezés, a helyreállítás, újjáépítés tapasztalatai, II, Belügyi Szemle, year 61, no.3, 2013.

19. PADÁNYI, József, Polgári-katonai együttműködés a békefenntartó müveletek során, ZMNE, Budapest, 2001.

20. ZORINÁCZ, Ádám, Egyházak a katasztrófavédelmi feladatrendszerben, Müszaki Katonai Közlöny, year XXI, no. 12, 2011, Budapest, URL: http://hhk.uninke. hu/downloads/kiadvanyok/mkk.uninke.hu/eloadasokpdf/3.csop/Zorinacz\%20 Adam.pdf.

21. ZSÁKAI, Róbert, A lelki segítségnyújtás jelentősége katasztrófák során, URL: https://www.knbsz.gov.hu/hu/letoltes/szsz/2014_1_szam.pdf, letöltve, 2021. 